\title{
The Relationship of Birth Weight Infant with Bacteriological Profile and Antibiotic Resistance of Neonatal Sepsis
}

\author{
Nisrina Asysyifa ${ }^{1}$, Husjain Djajaningrat ${ }^{2}$ and Diah Lestari ${ }^{3, *}$ \\ ${ }^{1}$ Health Polytechnic of Jakarta III \\ Jakarta, Indonesia) \\ ${ }^{2}$ Health Polytechnic of Jakarta III \\ Jakarta, Indonesia \\ ${ }^{3}$ Health Polytechnic of Jakarta III \\ Jakarta, Indonesia \\ *Corresponding author's email: Diahtari1411 [AT] gmail.com
}

\begin{abstract}
Neonatal sepsis is a major issue on neonatal-care field. This incident occurs by many factors, one of the factor is infant with a low birth weight. Blood culture is used as the gold standard for diagnosis. The spectrum of bacteria which caused neonatal sepsis is constantly change and vary due to antibiotic resistance phenomenon. This study aimed to determine the relationship of birth weight infant with bacteriological profile and antibiotic resistance of neonatal sepsis in RSAB Harapan Kita Jakarta. This study used observational method with cross sectional design and purposive sampling method which is analyzed by chisquare test. Medical record data and blood culture and antibiotic resistance test from all subjects in Januari until December 2018 were reviewed. The sample in this research is neonatal sepsis patients who met inclusion criteria were 51 patients. From $51(55,43 \%)$ subjects, there were 39 (76,47\%) neonatal sepsis in low birth weight infant. Klebsiella pneumonia spp (41,17\%) and Staphylococcus epidermidis $(19,60 \%)$ were the predominant pathogens. Amikacin (62,74\%), and meropenem (50,98\%) were the most susceptible antibiotic towards bacteria. Maximum resistance among organisms was seen in cefotaxime $(84,31 \%)$, ceftazidime $(78,43 \%)$, and amoxicillin $(70,58 \%)$. The result of the analysis found there is a relationship between birth weight infant and bacteriological profile (p-value $=0,035$ ), but there is no relationship between birth weight infant and antibiotic resistance of neonatal sepsis ( $p$-value $=0,092 ; 0,066$; and 0,521). There is a relationship between birth weight infant and bacteriological profile, but there is no relationship between birth weight infant and antibiotic resistance of neonatal sepsis.
\end{abstract}

Keywords— Birth Weight Infant, Neonatal Sepsis, Bacteriological Profile, Antibiotic Resistance

\section{INTRODUCTION}

According to World Health Organization (WHO), there are 5 million neonatal deaths globally with an estimated mortality 34 per 1000 live births, $98 \%$ of them occur in developing countries. The neonatal mortality rate in Indonesia was reported to be 20 per 1000 live births in 2002, which according to WHO are similar to the average for other Southeast Asian countries (19 per 1,000 live births). Meanwhile, according to the Indonesian Health Demographic Survey (IDHS), the infant mortality rate (IMR) is $32 / 1000$ live births.

The WHO's report which is quoted from State of World 's Mother 2007 reported that $36 \%$ of neonatal deaths were caused by infectious diseases, including sepsis, pneumonia, tetanus, and diarrhea. WHO also reports a high case fatality rate $(40 \%)$ in cases of neonatal sepsis. The incidence of neonatal sepsis in developed countries is 1-4 per 1000 live births with a mortality rate of $10.3 \%$ lower than developing countries which reach $10-50$ per 1000 live births with a mortality rate of $12 \%-68 \%$.

Sepsis is a significant cause of neonatal morbidity and mortality. Neonatal sepsis is a clinical syndrome of systemic disease due to infection during the first month of life. Bacteria, viruses, fungi, and protozoa can cause newborn sepsis.2 One risk factor for neonatal sepsis is low birth weight and very low birth weight. The incidence of neonatal sepsis is ten times higher in low birth weight compared to normal-born infants. The lower birth weight of an infant the higher the risk of sepsis, about $10 \%$ of babies with birth weight under 1000 grams and $50 \%$ of babies born under 750 grams. 3 Sepsis in neonates requires proper diagnosis and treatment in order to reduce mortality. Examination of blood culture is the gold standard for the diagnosis of neonatal sepsis. Blood cultures are carried out to determine the causative bacteria while 
conducting an antibiotic sensitivity test.1

The choice of antibiotics must be evaluated when culture results and sensitivity tests are available. The spectrum of neonatal infectious organisms always changes and varies within each hospital. Several studies have shown that the causes of different neonatal sepsis between hospitals are in line with the type of service in each section, the frequent occurrence of nosocomial infections and the health services for the community. The choice of antibiotics as a therapy has an important role in achieving patient recovery. Therefore, laboratory tests of sensitivity testing or antibiotic resistance testing are needed to select antibiotics appropriately and accurately.4

The research conducted by Pertin, et al. in 2012 there were $21.8 \%$ of neonatal sepsis occurance. Neonatal septis patients with bacteria resistance to both types of empirical antibiotics were the highest group of patients who died, $81.8 \%$. The most common type of microorganism is Staphylococcus sp. The highest number of deaths caused by Enterobacter sp (45.5\%). More Gram negative as a cause of 33/55 neonatal sepsis $(60 \%)$ and the most common cause in the deceased group was 9 out of 11 cases $(81.8 \%)$.

Based on SK Menteri Kesehatan No.HK.02.03 / I / 0924/2015, RSAB Harapan Kita Jakarta was established as a Class A on Mother and Child Hospital as the leading of women, perinatal and child health care units. Infection in the neonate caused by several types of bacteria and the use of antibiotics certainly obtain particular concern at RSAB Harapan Kita Jakarta. Therefore, this study aimed to determine the relationship of birth weight infant with bacteriological profile and antibiotic resistance of neonatal sepsis in RSAB Harapan Kita Jakarta.

\section{METHODS}

This study used an analytic observational with cross-sectional design analyzed by chi-square test. Data were obtained from medical records, blood culture and antibiotic resistance results of suspected septic neonates in the period January to December 2018 at RSAB Harapan Kita Jakarta.

The sample in this study were neonatal sepsis patients who fulfilled the inclusion criteria as many as 51 patients taken by purposive sampling.

The inclusion criteria of this study such as neonates who were treated at RSAB Harapan Kita Jakarta, patients were neonatal sepsis patients, the patient's status (returned home / died), and the patient examined culture and antibiotic resistance. While the exclusion criteria are babies born with congenital anomalies and patients with incomplete medical records. Diagnosis of neonatal sepsis is based on clinical symptoms, and results of blood culture examination. This study has obtained an ethical clearance from the Research Ethics Commission of RSAB Harapan Kita No: IRB / 10/02 / ETIK / 2019. Data analysis is done in univariate and bivariate test.

\section{RESULTS}

The There were 778 infants with suspected sepsis from January to December 2018 at RSAB Harapan Kita. Bacterial growth was found in $92(11.83 \%)$ specimens of blood culture. From 92 respondents' data, $29(31.52 \%)$ infants with congenital anomalies and $12(13.04 \%)$ infants had incomplete medical record data, so that only $51(55.43 \%)$ infants were fulfilled the inclusion criteria which born at RSAB Harapan Kita Jakarta with a diagnosis of neonatal sepsis. Male infants were the highest group of neonates with sepsis as many as $32(62.74 \%)$ infants, whereas only $19(37.35 \%)$ female infants with sepsis, seen in table 1.

Table 1. Frequency Distribution of Patients with Neonatal Sepsis Based on Gender

\begin{tabular}{ccc}
\hline Gender & Frequency & Percentage \\
\hline Female & 19 & $37,25 \%$ \\
Male & 32 & $62,74 \%$ \\
\hline Total & 51 & $100,00 \%$ \\
\hline
\end{tabular}

Late-onset sepsis was the most common cause of $45(88.24 \%)$ infants and only $6(11.76 \%)$ infants with early-onset sepsis, seen in table 2. 
Table 2. Frequency Distribution of Patients with Neonatal Sepsis Based on Onset Type

\begin{tabular}{lcc}
\hline Onset Type & Frequency & Percentage \\
\hline $\begin{array}{l}\text { Early-onset sepsis } \\
\text { ( }>72 \text { hours) }\end{array}$ & 6 & $11,76 \%$ \\
$\begin{array}{l}\text { Late-onset sepsis } \\
(>72 \text { hours) }\end{array}$ & 45 & $88,24 \%$ \\
\hline Total & 51 & $100,00 \%$ \\
\hline
\end{tabular}

Most patients with neonatal sepsis were low birth weight infants $(76.64 \%)$, followed by normal birth weight babies $(21.56 \%)$, and very low birth weight infants (1.96\%) (Table 3$)$.

Table 3. Frequency Distribution of Patients with Neonatal Sepsis Based on Birth Weight

\begin{tabular}{ccc}
\hline $\begin{array}{c}\text { Birth Weight } \\
\text { (gram) }\end{array}$ & Frequency & Percentage \\
\hline$<2500$ & 39 & $76,47 \%$ \\
$2500-3999$ & 11 & $21,56 \%$ \\
$\geq 4000$ & 1 & $1,96 \%$ \\
\hline Total & 51 & $100,00 \%$ \\
\hline
\end{tabular}

From blood culture result, it is obtained 13 species of bacteria as a leading cause of neonatal sepsis, which is Klebsiella pneumonia spp $(41.17 \%)$ in the first place, followed by Staphylococcus epidermidis $(19.60 \%)$ and Serratia marcencens $(7.84 \%)$ ( Table 4$)$.

The resistance pattern of some antibiotics used in this study can be seen in Figure 1. Antibiotics that have the highest sensitivity to bacteria were amikacin $(62.74 \%)$, while antibiotics with the highest resistance to bacteria were cefotaxime $(84.31 \%)$

Table 4. Frequency Distribution of Sepsis-Causing Bacteria

\begin{tabular}{|c|c|c|}
\hline Bacteria & Frequency & Percentage \\
\hline Klebsiella pneumoniae spp & 21 & $41,17 \%$ \\
\hline Staphylococcus epidermidis & 10 & $19,60 \%$ \\
\hline Serratia marcescens & 4 & $7,84 \%$ \\
\hline Acinetobacter baumannii & 3 & $5,88 \%$ \\
\hline Staphylococcus haemolyticus & 2 & $3,92 \%$ \\
\hline Staphylococcus hominis & 2 & $3,92 \%$ \\
\hline Burkholderia cepacia & 2 & $3,92 \%$ \\
\hline Escherichia coli & 2 & $3,92 \%$ \\
\hline hingomonas paucimobilis & 1 & $1,96 \%$ \\
\hline Acinetobacter iwoffii & 1 & $1,96 \%$ \\
\hline Staphylococcus aureus & 1 & $1,96 \%$ \\
\hline Korucia (Micrococcus) rosea & 1 & $1,96 \%$ \\
\hline Ralatonia pickettii & 1 & $1,96 \%$ \\
\hline Total & 51 & $100,00 \%$ \\
\hline
\end{tabular}




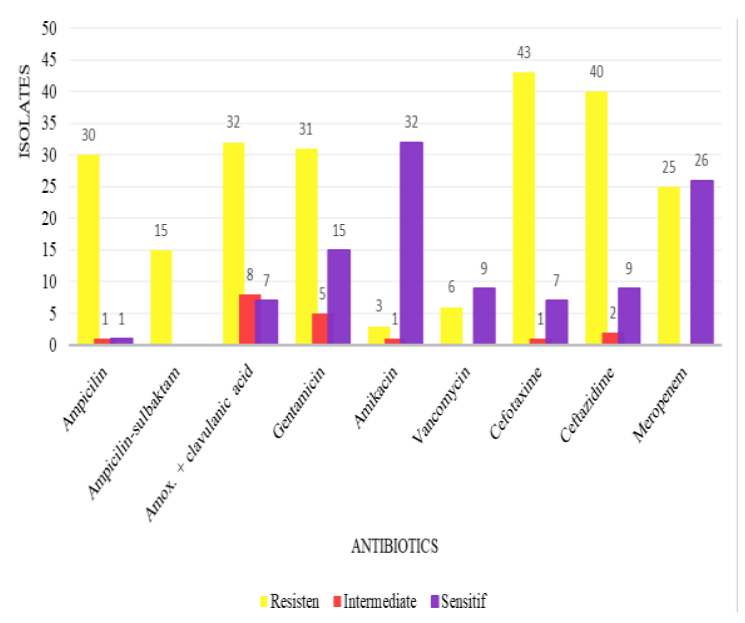

Figure 1. Antibiotic Resistance Pattern

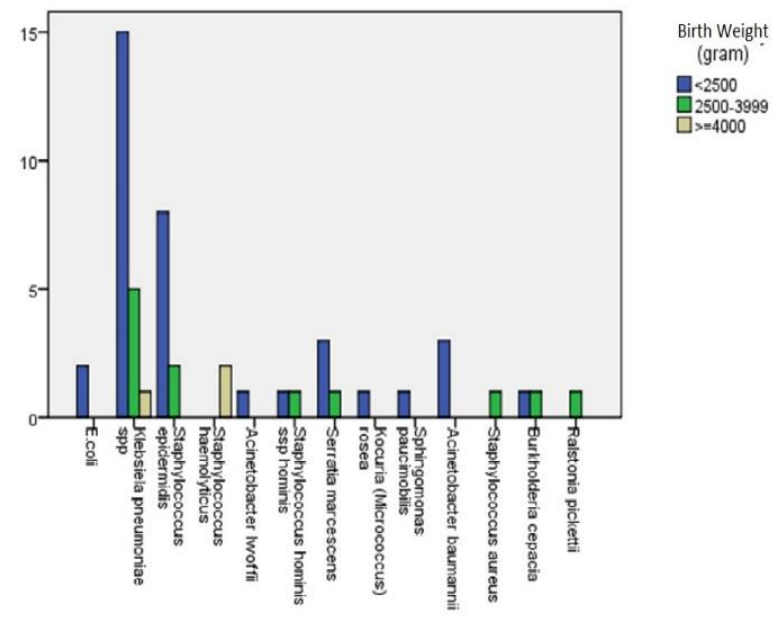

Figure 2. Frequency Distribution of Bacteria to Infant Weight Groups on Sepsis Patients
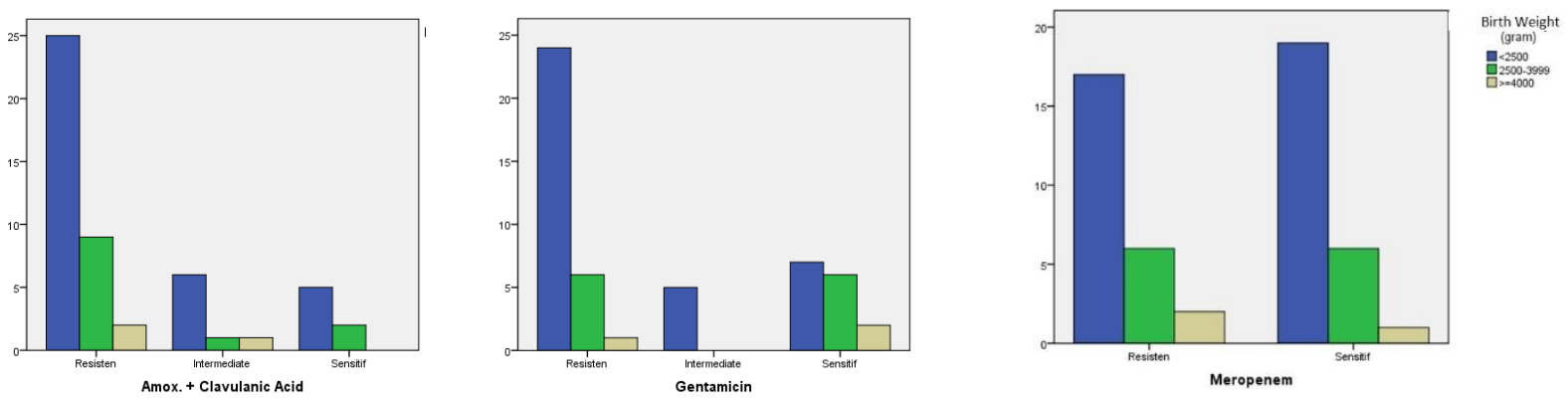

Figure 3. Antibiotic Resistance Pattern of Amoxicilin, Genamicin, and Meropenem against Low Birth Weight Group Patients with Neonatal Sepsis

The distribution of bacteria to groups of low birth weight $(<2500$ gr) sequentially was shown by the bacteria Klebsiella pneumoniae spp (33.33\%), Staphylococcus epidermidis (15.56\%), Serratia marcesens (5.88\%), can be seen in Figure 2. Amoxicillin antibiotic resistance rates for low birth weight infants was $52.94 \%$. While the level of resistance of gentamicin antibiotics to low birth weight infants was $50.98 \%$, and the level of antibiotic meropenem resistance to low birth weight infants was $35.29 \%$ (Figure 3).

The results of the statistical analysis on the relationship between the body weight of infants with the type of bacteria that causes sepsis showed the results of $p$ value $=0.035$. This shows a relationship between the infants's birth weight and 
the type of bacteria that causes sepsis. Whereas, the results of the Pearson chi-square statistical test obtained $\mathrm{p}$ value> 0.05 ( $\mathrm{p}$ value $=0.092 ; 0.066$; and 0.521$)$ indicating that there was no significant relationship between infant weight and antibiotic resistance in patients with neonatal sepsis.

\section{DISCUSSION}

Neonatal sepsis is a term commonly used to describe a systemic response to infection in a newborn. The incidence of sepsis in neonates is quite high in developing countries. There were 18 cases in every 1000 births compared to developed countries which range from 1 to 5 cases in every 1000 births. 1

From this study, neonatal sepsis patients tended to be male $(62.74 \%)$ than female $(37.25 \%)$. Djajakusli stated that in cases of neonatal sepsis, risk factors for men are four times higher to get affected than women and it is influenced by genes related to sex. The research conducted by Wilar said that this was more dominant due to sex-related factors in terms of host vulnerability to infection. The $\mathrm{X}$ chromosome may have genes that affect thymus gland function and immunoglobulin synthesis. Whereas men only have one $\mathrm{X}$ chromosome which is more susceptible to infection than women. 3,12

Neonatal patients in this study were more likely to have late-onset sepsis (88.24\%) which was a postnatal infection (more than 72 hours). In late-onset neonatal sepsis, the causative bacteria usually come from the outside environment or hospital. In addition, the lack of adherence of medical personnel to hand washing before and after examining infants, the location of handwashing too far from the position of cribs, the capacity of inpatients is too much, the excess number of medical personel and the uncontrollable people passing through the care room of high risk neonates, the use of equipments and invasive treatment such as parenteral nutrition, percutaneous catheter placement, or mechanical ventilation can cause bacterial transmission especially to infected neonates. 13,14

The results of the analysis show that there is a relationship between the body weight of infants with the bacteriological profile that causes sepsis $(p$ value $=0.035$ ). Theory from Norm and Must stated that low birth weight infants is relatively unable to form antibodies and the strength of phagocytosis and the reaction to inflammation is still not essentially good. Hence, the body's immune to infection decreases which low levels of 19G gammaglobulin will cause sepsis. Low birth weight babies have a greater risk to neonatal sepsis because in infants with low birth weight the maturation of their organs is not perfectly completed. In infants of normal weight, the first week after birth the baby's weight will decrease, then it will increase according to the baby's growth. In low birth weight babies, weight loss can occur at any time because there is usually a problem in breastfeeding. In low birth weight infants the main respiratory regulation is rudimentary, respiratory muscles and ribs are still incredibly weak which result in lacking of oxygen enters the brain, therefore anerobic germs will be easily develop which susceptible to an occurrence of infection.6,7 Initial therapy recommended in general is a combination of ampicillin and aminoglycosides ( gentamicin). The alternative to aminoglycosides is, third generation cephalosporins (eg: cefotaxime). This regimen is found to be safe and efficacy will last with the appropriate duration of therapy. Research shows that there has been resistance in almost three types of firstline antibiotics, ampicillin (58.82\%), gentamicin (70.58\%) and cefotaxime $(84.31 \%)$. These results are in line with the Rasyidah study conducted on neonatal sepsis in Dr. Pirngadi Medan City that almost all bacteria that cause neonatal sepsis are resistant to ampicillin $(83.1 \%)$, gentamicin $(54.2 \%)$, and cefotaxime $(72.9 \%)$.

The results showed that the majority of bacteria had experienced resistance to amoxicillin antibiotics $70.58 \%$, gentamicin $60.78 \%$, and meropenem $49.01 \%$. The results of the research conducted by Juniatiningsih at RSCM Jakarta showed that the bacteria that caused sepsis were resistant to ampicillin, gentamicin sensitivity $33.3 \%$ and to meropenem $100 \% .8,9$

The results of the analysis revealed that there was no significant relationship between infant weight and antibiotic resistance $(\mathrm{p}$ value $=0.092 ; 0.066$; and 0.521 ). The problem of antibiotic resistance is a universal problem. There is no doubt that excessive use of antibiotics creates resistance problems in the future. Broad-spectrum antibiotics cause more resistance than narrow-spectrum antibiotics. Therefore policies in the use of antibiotics must be present in each neonatal care unit.

\section{CONCLUSION}

The results showed that there was a relationship between infant birth weight and the bacteria that causes neonatal sepsis, but there was no relationship between infant birth weight and antibiotic resistance in patients with neonatal sepsis.

\section{ACKNOWLEDGEMENT}

The author would like to thank the Poltekkes Kemenkes Jakarta III and RSAB Harapan Kita Jakarta and all individuals involved for their contribution and assistance in the data collection process. 


\section{REFERENCES}

[1] Oyong, N., Anggraini, D. and Karina. 2016. Pola Resistensi Bakteri Penyebab Sepsis Neonatorum di Instalasi Perawatan Neonatus RSUD Arifin Achmad Riau. Sari Pediatri. Vol 17 No 6.

[2] Depkes RI. 2007. Penatalaksanaan Sepsis Neonatorum. Departemen Kesehatan Republik Indonesia: Jakarta.

[3] Wilar, R. et al. 2016. A comparison of neutrophil gelatinase-associated lipocalin and immature to total neutrophil ratio for diagnosing early-onset neonatal sepsis. Paediatrica Indonesiana. Vol 56 No 2: 107-110.

[4] Brooks, G. et al. 2012. Mikrobiologi Kedokteran Jawetz, Melnick, \& Adelberg. 25th edn. EGC: Jakarta.

[5] Sianturi, P. et al. 2012. Profil Sepsis Neonatus di Unit Perawatan Neonatus RSUP H Adam Malik Medan Tahun 2008-2010. Sari Pediatri. Vol 14 No 2: 67-72.

[6] Norma, N. dan Mustika, D. 2013. Asuhan Kebidanan Patologi Teori dan Tinjauan Kasus Dilengkapi Contoh Askeb. Yogyakarta: Nuha Medika.

[7] Simbolon, D. 2008. Faktor Risiko Sepsis pada Bayi Baru Lahir di RSUD Curup Kabupaten Rejang Lebong. Buletin Penelitian Kesehatan. Vol 36 No 3: 127-134.

[8] Juniatiningsih, A., Aminullah, A. dan Firmansyah, A. 2008. Profil Mikroorganisme Penyebab Sepsis Neonatorum di Departemen Ilmu Kesehatan Anak Rumah Sakit Cipto Mangunkusumo Jakarta. Sari Pediatri. Edisi Juni 2008. Vol 10 No 1: 60-65.

[9] Rasyidah. 2014. Pola Kuman dan Uji Kepekaan Antibiotik pada Sepsis Neonatorum di Unit Perawatan Neonatus RSUD dr Pirngadi Kota Medan. Sari Pediatri. Vol 3 No 1: 431-436.

[10] Hayatullah, M. K. et al. 2017. Terapi Antibiotika Empiris pada Neonatus. Journal of Medical School University of Sumatera Utara. Edisi Juni 2017. Vol 50 No.2: 107-110.

[11] Edy, Ferdy dan Latre. 2007. Pola Mikroorsganisme dan Sensitivitas dari Spesimen Klinik di UPIN dan "Intermediate ward"s. Sari Pediatri. Edisi. Juni 2007. Vol 9 No 1: 67-74.

[12] Djajakusli, S. et al. 2017. Profil Kematian Neonatus di RSUD dr. Soetomo. Jurnal Ilmu Kesehatan Anak. Vol 18 No 6: 474.

[13] Nasution, D. A. 2008. Faktor Risiko dan Kesamaan Jenis Bakteri Jalan Lahir Ibu dengan Kultur Darah pada Sepsis Neonatal Awitan Dini. Thesis. Jurusan Sains Biomedis Universitas Diponegoro. Semarang.

[14] Tavora AC, et al. 2008. Risk Factors for Nosocomial Infection in a Brazilian Neonatal Intensive Care Unit. The Brazilian Journal of Infectious Diseases. Vol 12 No 1: 75-79. 